\title{
Achieving innovation in a lean environment: How innovative small firms overcome resource constraints
}

\author{
David Deakins* and Jo Bensemann**
}

*Honorary Researcher, Department of Entrepreneurship, Strategy and Innovation, Lancaster University Management School, Lancaster University

**Associate Head of School, School of Management, Massey University 


\title{
Achieving innovation in a lean environment: How innovative small firms
}

\author{
overcome resource constraints
}

\begin{abstract}
This paper examines how innovative small firms achieve innovation within lean environments. Writers taking a resource-based view (RBV) approach to innovation by small firms in lean environments have argued that they are resource constrained through shortages of skilled labour, finance, and social networks. This paper builds on the RBV approach by adopting a dynamic capabilities (DCs) lens to investigate how innovative small firms adopt and acquire DCs to achieve innovation in a lean environment in a small country with an open economy that is distant from major markets. We argue that entrepreneurs will engage in pragmatic solutions to overcome resource constraints. We provide qualitative evidence from a programme of 30 interviews and find that innovative small firms achieve innovation through ingenuity and patience. Our entrepreneurs use methods such as bricolage and bootstrapping and make cooperative arrangements with early adopters to maximise use of their limited resources.
\end{abstract}

\section{KEYWORDS}

Innovation, agri-business, small open economy, small firms, New Zealand, dynamic capabilities. 


\section{INTRODUCTION}

This paper reports findings from a qualitative study of innovative small firms operating in a unique lean environmental context, that of the small and open economy of New Zealand. The purpose of the study is to examine how these firms achieve innovation with limited resources that are characteristic of such a context. The objectives of the paper are threefold: first, to examine strategic decision-making in the innovative behaviour of small firms and their techniques used to achieve innovation; second, to examine whether resource-based conceptual approaches can explain the behaviour and techniques that were adopted and, third, to contribute to the limited research on innovation management by small firms in resource-constrained environments (Löfqvist, 2017). The latter objective is concerned with contributing to a research gap in which there is currently limited research evidence (Löfqvist, 2017), previous research is reviewed as part of a literature review.

Theoretically, in such environments, the process of innovation management by small firms will be resource constrained. A resource-based view (RBV) (Barney, 1991) takes the approach that successful innovation will depend on access to human capital, especially skilled labour, sources of risk capital and intellectual capital through relationships developed with external networks (Teece, 1996). The RBV regards the firm as a unique bundle of tangible and intangible resources (Wernerfelt, 1984) and successful firms acquire and maintain assets valuable for creating sustainable competitive advantage. It is arguable that RBV is a static concept and that it is necessary to consider how a firm can develop capability to adapt to changing environments over time through a dynamic capabilities (DCs) approach (Teece, 2007). We build upon the RBV by using a DCs lens to investigate how innovative small firms adopt and acquire DCs to achieve innovation in a lean environment in a small and open economy that is distant from major markets. For this paper we adopt the following definition of DCs (Barreto 2010, page 271):

A dynamic capability is the firm's potential to systematically solve problems, formed by its propensity to sense opportunities and threats, to make timely and market-oriented decisions, and to change its resource base.

The RBV argues that a firm will have strategic competitive advantages when resources are valuable, rare, inimitable and non-substitutable (Barney, 1986; 1991), sometimes referred to as VRIN advantages. However, DCs add decision-making capabilities that are reflective of market opportunities and reconfiguration of its resource base (Barreto, 2010).

A firm may also be able to call on external resources from local or wider networks (Fang et al., 2017; Gulati, 1999) and social network theory, which is a closely aligned approach based on the RBV, suggests that the nature of a firm's social networks can influence the resourcefulness of firms through their ability to add value to their social capital (Fitjar et al., 2013). However, it has also been suggested that the process of innovation by innovative small firms is slower and more limited than in other (resource rich) environments (Smallbone et al., 1999). 
For example, in accessing entrepreneurial finance, rural entrepreneurs in this study typically do not have access to networks of business angels or private equity because those sources are less developed in New Zealand than in other OECD economies. New Zealand presents a unique contextual setting in which to examine entrepreneurial behaviour of innovative small firms because it is a small and remote economy with its small firms dependent on global markets. As mentioned, innovative small firms have traditionally been seen as resource-constrained, particularly in accessing finance and recruiting appropriate skilled employees (North et al., 2013). We can expect this issue to be more acute in a small and open economy that is distant from major markets such as that of New Zealand. This is important because it has been suggested that the neglect of contextual influences constitutes a major gap in the literature (Lang et al., 2014; Zahra and Wright, 2011).

Following from the purpose of this study, mentioned earlier, our central research question is stated as: How do innovative small firms achieve innovation with limited resources in a lean environment? The remainder of the paper is organised as follows: A literature review is provided that includes previous research and existing theory, we describe the research methodology, we present the qualitative findings and we return to our central research question in a discussion section before we conclude our paper with the implications for future research and the significance of the paper's contribution

\section{LITERATURE REVIEW}

This section reviews existing innovation management theories that focus on small firm capability and previous research that identifies the factors that affect the small firm innovation process when faced with scarce resources. As mentioned in our introduction, traditional management theories on innovation have centred on the RBV approach, but have not been developed to include DCs, where emergent themes include absorptive capacity and the improvement of capability through entrepreneurial learning and the utilisation of networks.

\section{The resource-based view (RBV)}

The resource-based view (RBV) can be seen as extending the traditional transaction cost theory of the firm (Coates, 1937), which essentially takes an internal perspective on resources commanded by management or the entrepreneur. Competitive advantage stems from having resources that are unique to the firm, valuable that cannot be replicated, imitated or substituted (Barney, 1991; Peteraf and Barney, 2003), as mentioned earlier, referred to as VRIN attributes. The VRIN resource-based model claims to explain differences in firm performance (Talaja, 2012). Such attributes of a firm's resources may take the form of intangible intellectual property or knowledge as well as skilled labour, which we would expect to be an important source of advantage for innovative small firms.

De Massis et al., (2018) take a RBV perspective in their study of German Mittelstand small and medium-sized enterprises (SMEs) and suggest that innovation is achieved through six key 
factors: niche focus and customer collaboration, globalisation strategy, preference for selffinancing, long-run mindset, superior employee relations and community embeddedness. Similarly, a RBV perspective by Henard and McFadyen (2012) indicates the importance of human resources, and particularly knowledge worker investments, for longitudinal and on-going returns. Finally, Kleinschmidt et al., (2007) use the RBV as the theoretical base for the contention that firms need to deploy organisational capabilities, to achieve new product development globally.

However, RBV approaches are criticised as being static and lacking dynamism (Fitjar et al., 2013), especially when new product development involves distinct development stages including $\mathrm{R} \& \mathrm{D}$ and prototyping which are part of a dynamic innovation process that will have considerable diversity across innovative small firms. Using a DCs lens allows modification of the RBV approach to address this issue and focuses on a firm's ability to renew and reconfigure its resource base. This is outlined in the following section.

\section{Dynamic capabilities and innovation}

The literature on DCs recognises that the environments and opportunities facing firms change over time and that management has a distinctive role in the strategic reaction to changing opportunities (Teece, 2007). Management of firms have to decide how to re-organise internal resources, such as staff and information, and how to combine these with partnerships external to the firm, such as with links to research institutions (Teece, 2009). Innovation is a complex process that may require the coordination of information across a number of groups and organisations over time (Fitjar et al., 2013). A DCs lens focuses on a firm's capacity to renew and reconfigure its resource base in the light of changing environments and new opportunities (Ambrosini and Bowman, 2009; Eisenhardt and Martin, 2000). This is sometimes referred to as capabilities that include 'sensing' and 'seizing' as well as reconfiguring or 'transforming'. (Castiaux, 2012; Plattfaut et al., 2015). Lawson and Samson (2001) have proposed an innovation capability construct at the firm level that includes seven elements: vision and strategy, harnessing competencies, organisational intelligence, creativity, organisational structures, culture and the management of technology. In theory, these elements enable the firm to sustain advantages in innovative capability over time.

It is useful to note that the dynamic aspect refers to intentional change of the firm's resource base, rather than changes in the environment (Ambrosini et al., 2009), implying that firms can build their resource base to respond to changing opportunities. A firm's competitive advantage still lies with its resource base, but capabilities are determined by management's capability to learn from practice and experience. In the context of innovative small firms, how entrepreneurs learn in changing environments is a critical aspect of DCs (Teece and Pisano, 1994).

Absorptive capacity and entrepreneurial learning 
A firm's capability to absorb and build on experience and learning over time is referred to as absorptive capacity. Absorptive capacity is an important component of DCs and focuses on a firm's capability to acquire, assimilate, process, transform and act on information and knowledge in order to exploit opportunities arising from the innovation process (Newey and Zahra, 2009; Zahra and George, 2002). Obviously, the role of the entrepreneur and entrepreneurial team is a key aspect here (Knudson et al., 2004). In the RBV approach, the absorptive capability of innovative small firms operating in a lean environment is expected to be restricted because of limits to both sources of information and the ability to exploit information through skilled labour (Parida and Örtqvist, 2015; Wernerfelt, 1984). Distance from major markets adds additional constraints in achieving innovation (Oxley et al., 2013).

Entrepreneurial learning is an important dynamic capability, particularly because innovation frequently arises through opportunities being recognised and exploited. (Corbett, 2002; Wang and Chugh, 2014). At the individual level, entrepreneurial learning has been recognised as containing the capability to apply specific entrepreneurial experience (Cope, 2005; Rae and Carswell, 2001). For example, experiential learning, or 'learning by doing', has been the focus of a number of papers (e.g., Cope, 2003; Morris et al., 2012; Politis, 2005; Thorpe et al., 2006), reflecting the importance of entrepreneurial and firm experience in framing entrepreneurial opportunities and entrepreneurial actions, making this capability a distinct form of individual learning. Theoretically, entrepreneurial learning, whether at the firm or individual level, may be seen as critical to innovative capability of small firms in a lean environment to ensure that available resources can be used to maximum effect in the innovation process, perhaps by assimilating information and sharing knowledge so that opportunities from innovation can be exploited (Chiva et al., 2014; Wang et al., 2015).

\section{Dynamic capabilities and using networks}

In theory, small firms experiencing resource constraints can use local networks to improve their dynamic capabilities, through collaboration to share knowledge, learning and expertise. Robinson and Stubberud (2012) concluded that a small firm can leverage resources through collaborative behaviour such as sharing of ideas, resources and capabilities. Regional networks within a globalised economy have been identified as important (Davenport, 2005; Gellyneck et al., 2007; Virkkala, 2007). International networks also can be strategically important (Rinnie and Fairweather, 2011). More recent literature has confirmed that networks can be significant for small firm capabilities (Shamsuzzoha and Kindi, 2016; Singh and Stout, 2018). Karlsson and Warda (2014) indicate important issues that need to be investigated in future research studies include how networks are used and the diversity of small firm communication methods.

Achievement through such cooperation with strategic partners has led to the claim that open innovation is important for improving, for example, access to sector knowledge bases (Aslesen and Freel, 2012). The importance of this access has been recognised within the agri-business sector (e.g., Svensson et al., 2012) and these studies support the theoretical view that networks 
offer the resource-constrained innovative small firm a means of accessing a wider knowledge base and greater strategic resources, leading to open innovation systems. However, it has also been argued that international networks are more important strategically than local or regional networks. For example, in a study of innovative SMEs in New Zealand, Davenport (2005) pointed to the importance of global, rather than local, sources and networks for knowledge acquisition.

Social network theory helps to explain the circumstances in which individuals and organisations can gain value from social networks and thereby increase their social capital, in this way it fits with the RBV. A business can gain value from a network through strong or weak ties (Granovetter, 1973). Strong ties and trust are complementary and are important for transferring tacit knowledge, such as knowledge of innovations; weak ties are more important for transferring information about complex knowledge.

\section{Previous research}

Previous research has indicated that small firms, when faced with scarce resources in lean environments will adopt management techniques that achieve innovation with limited resources, in particular through financial bootstrapping and bricolage. These techniques are defined and explained here as they feature in our discussion of findings later in the paper.

Financial bootstrapping involves a reliance on internally generated funds, rather than seeking external finance, and eliminating the need for external finance by securing resources at minimum or reduced cost (Harrison et al., 2004). Financial bootstrapping involves a combination of techniques that avoids raising finance. For example, Löfqvist (2017), using qualitative comparative case studies on small companies undertaking product innovation, found that the case study companies used different forms of financial bootstrapping in combination. These companies used bootstrapping in three ways: for increasing resources, for using existing resources more efficiently and for a fast payback for resources put into product innovation. Financial bootstrapping is likely to be more prevalent in start-up companies rather than established firms that have track records. Bhide (2000) in his study of 100 start-up companies found that bootstrapping is the norm rather than the exception. Studies with technology-based growth companies indicate that bootstrapping is frequently used in early stages, but then declines as firms seek external finance to support later growth (Patel et al., 2011).

Bricolage is 'making do' with existing or alternative resources, or what firms have available (Strauss and Corbin, 1998). For example, Baker and Nelson interviewed 29 resource-constrained small firms in poor environments and found that by recombining elements at hand for new purposes, that is, bricolage, "explained many of the behaviors we observed in small firms that were able to create something from nothing by exploiting physical, social or institutional inputs that other firms rejected or ignored" (Baker and Nelson, 2005, page 329). Bricolage may logically go alongside bootstrapping when small firms are faced with limited resources. 
The research record suggests that when small firms are faced with resource poor environments they will resort to management techniques that use existing resources that are flexible and resourceful, as well as utlising their social networks. For example, Jones and Jayawarna (2010) indicate that social networks help new businesses to acquire bootstrapped resources. Thus, when faced with lean environments, context and social networks will influence the capability of small innovative firms to adopt techniques of bootstrapping and bricolage (Löfqvist, L. (2017).

\section{RESEARCH METHOD}

The qualitative approach was purposefully selected for this research because our objectives were to understand the role of factors that affect the process of innovation and the perceptions of entrepreneurs within the subject community, that is, entrepreneurs of innovative small firms (McKeever et al., 2015; Pratt, 2009). The qualitative approach provides a way of locating the issues in context, both conceptually and empirically. Specifically, we used theory (based on the literature) as the framework for asking the questions, and we went beyond description to seek explanations about factors that affect the role of innovation. In doing so, we solicited a variety of responses to this from our respondents. Investigations into small firm innovation management behaviour have adopted qualitative methods, such as face-to-face interviews and comparative indepth case studies, because these methods are necessary in small companies to gain the trust of respondents who are often the owners of small companies. A qualitative approach enables indepth insights into their decision-making behaviour in the process of innovation (Baker and Nelson, 2005; Löfqvist 2017).

The number of interviews conducted with qualitative research should be guided by issues such as recurring themes, saturation of issues, different contexts and, with innovative small companies, different technological timescales to capture dynamic capabilities (Jack, 2005; Pratt, 2009; Strauss and Corbin, 1998). In this study, a sample of small companies from the same agribusiness sector, still contained a diversity of technological bases (such as IT applications, engineering and life-sciences) and contexts (urban, semi-rural and rural). Therefore, the number of interviews represented a balance between coverage of different contexts and achieving saturation. This process is in line with previous qualitative research examining innovative behaviour of small companies (Baker and Nelson, 2005).

Our sampling was purposeful (Gartner and Birley, 2002; Pratt, 2009), with 34 principal respondents from a diverse range of agri-business firms. From these 34 respondents, four were excluded for analysis because, although they were concerned with change, they did not meet the criteria to be actively engaged in technological developments in the agri-business sector. Two of the companies that were excluded were involved in animal feed products, one was a microbrewery and one was an organic fruit producer. Some respondents were identified from local knowledge and from contact with local business development organisations and incubators. Later the presence of the researchers in the various communities allowed identification of additional respondents through snowball sampling. The choice of new respondents was driven primarily by 
what they might contribute to the emerging theory (Alvesson and Skoldberg, 2000; McKeever et al., 2015). For additional background, we also interviewed a further nine key informants recruited from existing contacts. They were representatives of agencies working closely with our entrepreneur respondents and they provided a more institutional view, along with helping us to understand broader contextual factors.

For data collection, we undertook a qualitative in-depth interview programme. The face-to-face interviews were conducted using an open-ended interview guide. The interviews were loosely structured, starting with broad questions about the individual respondent's business and innovation activity, with subsequent questions arising through dialogue between the researcher and the respondent. It was important for the interviews to be sufficiently open-ended to allow for the exploration of additional themes from the data. The nine interviews with key informants were used to provide thick description (Geertz, 1973; Jack, 2005; McKeever et al., 2015; McKelvey, 2004) and a more nuanced picture of the agri-business and technology environment. This research approach allowed for significant patterns to emerge as they cut across multiple experiences of respondents (Patton, 2002). Low risk ethical approval was obtained from Massey University's Human Ethics Committee and interview respondents were offered the opportunity to review the transcripts and make changes before analysis of anonymised transcripts was undertaken.

\section{Coding of the interviews.}

Specifically adopting the lens of DCs for this research, three components of DCs specified in the literature (Baretto, 2010) were used for coding the qualitative data: entrepreneurial learning and absorptive capacity, utilising networks and pragmatic, action-based solutions. Two further categories, those of patient behaviour and bootstrapping emerged from the transcripts and are added to the analysis as shown in Tables 1 to 5. Although all companies are allocated into one of these five tables, it should be noted that there is cross-over because some companies demonstrated multiple components of DCs, patient behaviour and internal bootstrapping or bricolage. The five tables provide detail on the following:

1. Entrepreneurial learning and absorptive capacity

2. Utilising networks

3. Pragmatic action-based solutions

4. Patient behaviour

5. Bootstrapping and bricolage

The interviews ranged between one and two hours in length and were recorded and transcribed verbatim. An expanded set of notes was made within four hours of the interview to fill in details and to recall things that were not recorded in notes during the interview. The authors met to discuss these experiences and recordings, forming an introspective record of field work, enabling 
the authors to take into account personal biases and feelings and to understand their influence on the research (Emerson et al., 1995; Salvato and Corbetta, 2013).

As is typical in inductive research (Miles and Huberman, 1994), we analysed the data by first building individual summaries and then by synthesizing and comparing the interview transcripts and our field notes collected after the interviews. Analysis was undertaken with QSR NVivo qualitative data analysis software, utilising nodes derived from theory, but also allowing new codes and nodes to be established from the data.

\section{RESULTS}

In this section, we organise our analysis by utilising the themes identified from the literature review. Building on the RBV approach, DCs help to explain entrepreneurial behaviour in uncertain and lean conditions and we show how entrepreneurs used their DCs through the themes illustrated by Tables 1 to 5 .

\section{Dynamic capabilities: Entrepreneurial learning and absorptive capacity}

As indicated in the literature review, entrepreneurial learning, combined with absorptive capacity are key factors in dynamic capabilities. Together these determine a firm's capability to build and reconfigure resources over time. Evidence from the interviews indicates that entrepreneurial learning had a key role to play in innovation and subsequent entrepreneurial behaviour and strategy (see Table 1). The learning derived ranged from issues concerned with the basics of being in business to more technical issues arising from developing technology and the commercialisation in the new product development process.

The ability to absorb lessons gained from experience (i.e., experiential learning) which is the basis of entrepreneurial learning (EL) and this is key to building and reconfiguring resource capability in innovative small firms. Examples of experiential EL include learning from the experience of simply being in business, experience with new product development, learning from failure and learning from trial and error.

Table 1 shows that the respondent from firm \#05 discussed the importance of experiential learning; learning by doing, simply from being in business. Learning from failure is illustrated from the respondent from firm \#16 and building and reconfiguring capability from trial and error is illustrated by the respondent from firm \#26, but this was also as a result being able to reconfigure capability and demonstrating absorptive capacity (AC).

Other pragmatic solutions to building and reconfiguring capability were found through experiential EL, demonstrating AC. Firm \#29 was able to learn and gain knowledge on market opportunities, but also had the patience to secure local private equity through an angel investor. Firm $\neq 30$ demonstrated patience to learn by trial and error, from 'hard experience', but gained valuable assistance from one of their directors, who had the knowledge and skills to 'coach' the 
founding entrepreneurs through staged process of growth. This firm could be considered a 'born global' since they did not have any customers in Australasia.

<Take in Table 1 here>

\section{Dynamic capabilities: Using networks}

Membership in strategic networks was important for all of our innovative small agri-business firms, for sharing information and knowledge and for forming more strategic partnerships. Examples of the importance of networks for sharing information are discussed below and more detail is in Table 2. It is clear that these networks are not limited to the agri-business sector, but can be cross-sector. Acquiring information over time is important and firms emphasised local networks rather than global networks.

An example of the sharing information from a cross-sector relationship is firm \#05, from a respondent who mentioned the value of a network of women founders of innovative small firms. Respondents used networks to build capability and knowledge over time (\#13) and to gain knowledge on product utilisation through a close network of dairy farmers (\#25).

As noted in the literature review, networks can lead to collaboration, an important way to build capability and extend the resource base of the firm (Aslesen and Freel, 2012). Customers can be part of an extended resource base when they are used in co-creation. For innovative firms in agribusiness, customers can be an important test bed of new ideas and prototype developments. When customers are willing to test new developments, they become early adopters, which can be an important addition to a firm's resource base and a source of competitive advantage. This is a distinctive form of close collaboration in which the firm develops the innovation, rather than through user innovation, but the customer is still a valuable resource through trial testing of prototypes and providing feedback.

An example of this is the respondent from firm \#05 (Table 2) who could draw on customers as both early adopters and, effectively, as part of a network of sales centres. The role of early adopters in local markets and local networks was important, not just as a testing ground, but also for demonstration purposes. The founding entrepreneur with firm \#05 indicated that their customers (New Zealand dairy farmers) were early adopters who can provide information to other potential customers. Global networks can, for some innovative small firms, be more important than local networks, implying proximity in other dimensions, such as organisational, product or industry. However, the majority of our sample stressed the importance of strategic local networks.

$<$ Take in Table 2 here $>$

Dynamic capabilities: Pragmatic, action-based solutions 
Our evidence suggests that, faced with a lean environment, innovative small firm entrepreneurs resorted to pragmatic, action-based solutions for building and reconfiguring their resource base over time. In describing the environmental context of New Zealand earlier, we noted that sources of venture capital and business angel finance are limited. Limited sources of finance can lead to pragmatic, action-based solutions to building and reconfiguring financial resources.

For all of our innovative small firms, there was a strong reliance on internal funding. This did not appear to restrict new product development and innovation, although the lack of external sources did contribute to a slower pace of innovation and change. Entrepreneurs were willing to search for and obtain private equity investors through their own network of contacts and these were preferred to seeking angel or VC funding. In one case, a firm (\#07, Table 3) was able to develop the funding relationship it needed through greater recognition achieved through business awards success.

Table 3 provides three examples of companies that worked closely with their customers to gain feedback and involve them in co-creation: $\neq 01, \neq 07$ and $\neq 08$. Other examples of pragmatic actions are provided by cases $\neq 09, \neq 20$ and $\neq 24$. When firm $\neq 09$ was faced with the option of moving to a new location, they took an alternative strategy to make additional capacity at their current site, making use of existing resources. Firm $\neq 20$ used a beta test site (that of ice cream vans) to test their remote temperature monitoring equipment. Finally, firm $\neq 24$ applied technology developed for other uses (shower technology) to an opportunity in farming, again

illustrating the importance of having local customers who could trial new applications and products.

$<$ Take in Table 3 here>

\section{Patient behaviour}

Table 4 illustrates a number of examples of patient behaviour by our respondent companies. These include long term customer trials, long periods of R\&D, a search process for local capital, examples of trial and error and gaining knowledge from networks over a long period of time. For example, the respondent from firm $\neq 02$ discussed how he was prepared to spend time, proactively with customers at trade fairs. The respondent from firm $\neq 06$ told us the company had spent 27 years working with farmers to develop the company's specific software, an example of utilising customer feedback over a long period of time, but a willingness as well to spend time with other institutions including accountants and bankers. Similarly, firm $\neq 11$ worked with farmers who, as customers, were willing to pay for their prototypes, trial them and provide feedback. Even though firm $\neq 15$ was in receipt of a grant, they were still dependent on customer feedback from trials to develop their fertiliser product to meet new regulations. 
As would be expected from operating in a lean environment, there are further examples of patient behaviour in seeking and acquiring finance. The respondent from firm \#14 was prepared to carefully manage the pace of innovation and to change the development trajectory of his firm, rather than seek borrowing or large scale equity investment. A high level of patience was also evident in innovative small firms who were prepared to undertake a search procedure for private equity investment. Firm \#17 had sought finance from its start-up phase, but patience was exercised until they could form a team of investors who had local knowledge and had earned the firm's trust, an important part of local networks and social capital.

Patience in developing resources is different from pragmatic actions and illustrates different timescales involved in dynamic capabilities. Actions and dynamic capabilities that involved patient behaviour are identified for illustrative purposes. For example, the entrepreneur in firm \#14 has developed telemetry systems for over 30 years through patient R\&D including, prototypes trials with customers and customer feedback.

The remaining four cases in Table $4(\neq 19 ; \neq 21 ; \neq 23$ and $\neq 27)$ illustrate long development times, even though they were reliant on one product. Sometimes financial issues are solved through having an alternative income, as with the respondent in case $\neq 23$, who had some consultancy income, while working with a partner to develop their application of a biotechnology product. Other firms are well-established and use internal resources, as is the case with firm $\neq 21$, which has 'long roots' in their sector. Another approach is through continuous innovation and reinvestment of internal resources and firm $\neq 27$ is an example of this.

<Take in Table 4 here>

\section{Bootstrapping and bricolage}

There are a number of ways for entrepreneurs to engage in financial bootstrapping such as utilising trade credit, accessing internal funds, using alternative incomes and stretching resources to reduce costs. Table 5 illustrates some of these different pragmatic methods from our case companies. It is well accepted that accessing finance is difficult for small companies, limiting resources. This is nicely illustrated by case $\neq 03$ who, faced with limited funding, this reduced their capability to undertake detailed research to validate the results of their product. However, by foregoing such expenditure, they have still utilised their limited funding to achieve growth. The respondent with firm $\neq 04$ achieved early stage development by utilising an alternative income. Cases $\neq 10$ and $\neq 22$ are success stories, long-established companies, they have ensured they are early developers of new technology through internal resourcing, but stretching such resources over time.

Bricolage provides an additional means to stretch scarce resources by utilising equipment in different ways (e.g., as an alternative to expensive investments) and to meet customer requirements. Case $\neq 12$ illustrates the resourcefulness of a company that was able to reduce its operating costs by making its equipment mobile so that its raw material (flax oil) could be 
processed locally. Similarly, case $\neq 28$, a long-established engineering company, shows how the capability to demonstrate solutions on customer premises (i.e., mobile solutions) and make equipment work in different ways paid eventual dividends through the building of its customer network. This case illustrates the use of networks over time with customers, from which entrepreneurial learning provided the capability to apply the eventual pragmatic solution. Whether such patient behaviour is more characteristic of innovation of small firms in more rural environments is a question that we examine in the Discussion section that follows.

$<$ Take in Table 5 here>

Coupled with these extensive search processes was the gradual emergence of dedicated business angel networks within the agri-business sector. There is some evidence that fledging local and regional business angel networks have now become more mature and are actively investing in New Zealand innovative small firms in the agri-business sector. One firm that found such a local solution was case \#29 and this is illustrated by the discussion of the respondent in Table 1.

A longer search process may be involved In a lean environment with immature finance markets a longer search process may be involved than in more munificent or more mature environments. Not surprisingly, such search processes may not be fruitful, or even not be undertaken by entrepreneurs prepared to engage in bootstrapping, making resources stretch and pragmatic action such as pacing the management of innovation and change. These and other pragmatic and action-based solutions are given more focus in the next section.

\section{DISCUSSION}

In this section we return to our central research question: How do innovative small firms achieve innovation with limited resources in a lean environment? We discuss our qualitative evidence in the light of the theories that were introduced in our literature review and were used to frame our data collection and analysis of findings. Two other issues that arise from our findings are also discussed in this section; whether pragmatic actions and solutions are distinct from patient behaviour and whether context in lean environments matters for small companies.

\section{Dynamic capabilities}

DC theory can be seen as an extension of the RBV approach, as outlined earlier. In a lean environment, where resources are limited and scarce compared to more bountiful environments, we can expect that entrepreneurs will seek to build and reconfigure their resource base by making their limited resources stretch further. Strategies to do this include bootstrapping, utilising knowledge from close ties with local networks and recruiting local labour that may require up-skilling and training, but may also be more loyal to a local employer.

A DCs approach is still supported, but we have seen that these search processes may take longer and that entrepreneurs will seek pragmatic solutions to resource-based issues. For example, two 
firms (\#12 and \#28) how they sought to make equipment and machinery work in new applications, thus providing examples of bricolage, resourcefulness, ingenuity and patient behaviour that provided pragmatic solutions. Similarly, firm \#14 had to make the equipment to be mobile and operate in different locations. This not only illustrated the nature of entrepreneurial learning that was identified in our literature review, but also the need for capability and ingenuity to make it work successfully. Firm \#32 provides a similar example: a long-established family industrial engineering business used their knowledge, resourcefulness and capability to create a mobile demonstration trailer unit that they could take on site to demonstrate to potential buyers such as farmers and small food and beverage manufacturers.

The literature indicated that external networks were important for innovative small firms to source information, additional resources and cooperation to expand their resource base (Cannarella and Piccioni, 2010; Davenport, 2005; Gellyneck et al., 2007; Virkkala, 2007). Indeed, we found that local networks were important as a source of information, for sharing experiences and for obtaining resources. Significantly, local networks have maintained their importance over time. Local networks were also used as a means of building knowledge of and trust with potential private equity investors.

Both sector-specific networks and cross-sector networks were represented in terms of relationships and ties developed by our innovative small firm respondents. Cross-sector networks were important for sharing information and for developing contacts. More specialised sector networks were characterised by closer ties and provided an important channel for additional resources. For example, the role of early adopters within the sector was a critical factor for the innovation process, not only providing feedback on prototypes and $R \& D$, but also acting as potential sales centres through the demonstration of the viability and worth of new products and processes.

\section{Bootstrapping, bricolage and early adopters}

Entrepreneurs in our sample of agri-business innovative small firms employed techniques of bootstrapping, bricolage, and utilising customers as early adopters. These pragmatic management techniques illustrate how small firms achieve innovation when resources are limited in a lean environment. Developing such techniques obviously requires resourcefulness and ingenuity to adopt such methods and to build absorptive capacity. All three techniques are ways of making resources stretch further and can be seen as an adaptation to lean environments.

The role of finance as a resource constraint on the innovation process was more complex than might be expected. There was the reliance on internal sources that was expected. Furthermore, it was apparent that entrepreneurs preferred internal sources, using domestic market revenues and utilising financial bootstrapping methods, as well as delaying growth and investment, in order to ensure that new product development could be funded internally. However, it was also evident that innovative small firms were able to undertake a search process, which could take some time 
and patience, in order to obtain external finance from a preferred equity investor or from a specialised sector-based business angel network.

Faced with limited access to entrepreneurial capital and recruitment from the skills base, entrepreneurs will seek to make existing equipment and machinery work in new ways through bricolage. They do this when new technology is too expensive to import. Similarly, they will also be willing to recruit employees whose skills may not match immediate firm requirements and train these employees to meet the firm's requirements.

Bootstrapping techniques are well known in all environments, but the need for bricolage and cost reduction methods is more obvious in lean environments and, especially, over lengthy time periods. There will also be greater search activity for local risk capital from private equity investors, often from the same sub-sector. This produces more patient capital than might the case in other environments.

In lean environments, utilising early adopters was one method employed to reduce costs. Early adopters are recruited from local networks or the customers base to provide the test bed and to provide valuable feedback on prototype developments.

These three techniques provide innovative small firms with ways of adapting to a lean environment, extending their resource base and utilising ingenuity. These are strategic actions that are pragmatic solutions to the scarcity and limitations of resources in a lean environment.

Turning to whether such pragmatic techniques are distinct from patient behaviour, we see respondent patience, where demonstrated, as providing an additional dimension. For example, as we discussed with the respondent from firm \#14, patience provided an additional important dimension that adds to the concept of dynamic capabilities required by innovative small firms, faced with scarce resources in lean environments. It is more likely that patience will be an additional capability required in more rural environments.

This leads to our third issue: Does context matter? The results of this research support previous research which has suggested that different contexts, such as rural or urban environments, do matter for small innovative firms. Pragmatic techniques that we have discussed - bootstrapping, bricolage, utilising early adopters - are characteristic behaviours of small innovative firms in different contexts, yet they take longer and require more of the additional capability, that of patience, in more rural areas. We do not report detailed findings on this issue here, but in a separate paper we have examined differences in behaviour in such techniques in 16 urban firms and 14 rural firms (Deakins and Bensemann, 2017).

\section{CONCLUSIONS}

The qualitative evidence presented here indicates that in a lean environment, such as New Zealand, innovative small firms do not behave as if resource constrained, although the 
innovation process may take more time and require more patience than in resource rich environments. Entrepreneurs are able to use their ingenuity and adopt pragmatic techniques such as financial bootstrapping, bricolage, and the utilisation of customers as early adopters. Patience adds an extra dimension to the dynamic capabilities that enable access to resources to overcome constraints. This is particularly important in rural environments, where networks may take longer to develop. These pragmatic techniques are part of a small firm's dynamic capabilities. Our evidence suggests that they are important techniques that contribute to resilience in lean environments. We cannot comment on whether they are significant factors for performance in innovative small firms, this would require a larger more quantitative study. However, we suggest that these pragmatic solutions (e.g., managing with existing internal resources) are part of the dynamic capabilities that can be acquired by innovative small firms over time.

Knowledge, information and trust are built in local networks, and so these networks are important for the majority of innovative small firms, with the exception of specialised life science firms. We found that although sources of private equity and business angel networks were limited, as might be expected, local networks were nevertheless well established. Furthermore, the trust that was built over time lead to the emergence of specialised sector private equity investors and angel networks. This was an additional reinforcing factor behind the importance of local networks for innovative small firms in resource-constrained environments.

We make a distinction between these pragmatic techniques and patient behaviour in our innovative small firms. Patient behaviour is an important technique that adds to dynamic capabilities and should be examined by further research with other firms in different contexts, and whether the same processes are at work in larger firms. Patient capital is generally difficult a small firm to acquire, for innovative small firms it may require development of local networks that can enable sector-specific private equity investors to acquire knowledge and opportunities for investment. In our study, the development of such resources was evident in sub-sectors, such as fruit production, within the agri-business innovative firms. The development of patience as a dynamic capability of small firms should form the basis for more longitudinal research that can yield insights into potential blockages, problems and key success factors in this process.

The relative importance of local networks, compared to global networks, is an area that deserves further research to confirm our findings for small innovative firms faced with scarce resources in a lean environment. Similarly, investigations with large firms could examine the benefits and challenges of local networks and whether these issues that are more characteristic of small firms. It is likely that the nature of the lean environmental context means that innovative small firm entrepreneurs were forced to depend on their ingenuity and resourcefulness, seeking ways to ensure that resources could be adapted. For example, without resources for expensive laboratories, the recruitment of local customers as early adopters created an important test bed for prototypes and new product development. These early adopters became both a proving ground for the development stage of innovation and a marketing mechanism. In addition, the entrepreneurs sought ways to ensure that limited resources could be applied in flexible ways, 
examples being to make demonstration units more mobile and ensure existing machinery can work in different applications, both of which we describe as examples of bricolage.

This paper has provided evidence-based research on the importance of different types of small firm innovation management behaviour in the context of scarce resources in a lean environment. This contribution will be important to theorists for the development of conceptual frameworks that will provide an understanding of decision-making behaviours and the use of pragmatic activities such as financial bootstrapping and bricolage. Such frameworks should provide a grounding for future research investigations into this area.

We suggest that network theory, combined with resource-based approaches such as DCs, offers a conceptual framework for understanding the action-based responses and entrepreneurial behaviour of innovative small firms in lean and rapidly changing environments. Further research is required to confirm our conclusions.

The research limitations of our study include that the findings apply in a specific context. Further work could make comparisons with resource rich environments. Of course, resource rich environments do not necessarily mean access to a rich resource base or even sustained competitive advantage. Instead, we suspect that practices such as bootstrapping, bricolage and using early adopters will still be in evidence in innovative small firms in different environments, but the manner in which they are used and their importance are likely to differ. 


\section{REFERENCES}

Alvesson, M. and Skoldberg, K. (2000) Reflexive methodology: New vistas for qualitative research. London: Sage.

Ambrosini, V. and Bowman, C. (2009) What are dynamic capabilities and are they a useful construct in strategic management? International Journal of Management Reviews, 11 (1), 2949.

Ambrosini, V., Bowman, C. and Collier, N. (2009) Dynamic capabilities: an exploration of how firms renew their resource base. British Journal of Management, 20 (1), S9-S24.

Aslesen, H.W. and Freel, M. (2012) Industrial knowledge bases as drivers of open innovation? Industry and Innovation, 19 (7), 563-583.

Baker, T. and Nelson, R.E. (2005) "Creating something from nothing: Resource construction through entrepreneurial bricolage", Administrative Science Ouarterly, 50, 329-366

Barney, J. B. (1986) Organizational culture: Can it be a source of sustained competitive advantage? Academy of Management Review, 11 (3), 656-665.

Barney, J. B. (1991) Firm resources and sustained competitive advantage. Journal of Management, 17 (1), 99-120.

Barreto, I. (2010) Dynamic capabilities: A review of past research and an agenda for the future. Journal of Management, 36 (1), 256-280.

Bhide, A. (2000) Bootstrap finance: The art of start-ups. Harvard Business Review, 109-117

Castiaux, A. (2012) Developing dynamic capabilities to meet sustainable development challenges. International Journal of Innovation Management, 16 (6).

Chiva, R., Ghauri, P. and Alegre, J. (2014) Organizational learning, innovation and internationalization: A complex system model. British Journal of Management, 25, 687-705.

Coates, R.H. (1937) The nature of the firm. Economica, 4 (16), 386-405.

Cope, J. (2003) Entrepreneurial learning and critical reflection: Discontinuous events as triggers for 'higher-level' learning. Management Learning, 34, 429-450.

Cope, J. (2005) Toward a dynamic learning perspective of entrepreneurship. Entrepreneurship Theory and Practice, 29 (4), 373-397.

Corbett, A.C. (2002) Recognizing high-tech opportunities: learning and cognitive approaches. In W.D. Bygrave, C. Brush, P. Davidsson, J. Fiet, P. Greene, R.T. Harrison, M. Lerner, G. Dale 
Meyer, J. Sohl, and A. Zacharakis (Eds.). Frontiers of Entrepreneurship Research, 49-61. MA: Babson College.

Davenport, S. (2005) Exploring the role of proximity in SME knowledge acquisition. Research Policy, 34 (5), 683-701.

Deakins, D. and Bensemann, J. (2017) Does a rural location matter for innovative small firms? Proceedings of the $15^{\text {th }}$ Rural Entrepreneurship Conference, Newcastle, June.

De Massis, A.D., Audretsch, D., Uhlaner, L. and Kammerlander, N. (2018) Innovation with limited resources: Management lessons from the German Mittelstand. Journal of Product Innovation Management. 35 (1) 125-146

Eisenhardt, K.M. and Martin, J.A. (2000) Dynamic capabilities: What are they? Strategic Management Journal, 21 (10-11), 1105-1121.

Emerson, R.M., Fretz, R.I. and Shaw, L. (1995) Writing ethnographic fieldnotes. Chicago, IL: University of Chicago Press.

Fang, S., Wang, M., and Chen, P. (2017) The influence of knowledge networks on a firm's innovative performance. Journal of Management \& Organization, 23 (1), 22-45.

Fitjar, R.D., Gjelsvik, M. and Rodriguez-Pose, A. (2013) The combined impact of managerial and relational capabilities on innovation in firms. Entrepreneurship and Regional Development, 25 (5-6), 500-520.

Gartner, W. and Birley, S. (2002) Introduction to the special issue on qualitative methods in entrepreneurship research. Journal of Business Venturing, 17 (5), 387-395.

Geertz, C. (1973) The interpretation of cultures. New York: Basic Books.

Gellyneck, X., Vermeire, B. and Viaene, J. (2007) Innovation in food firms: Contribution of regional networks within the international business context. Entrepreneurship and Regional Development, 19 (3), 209-226.

Granovetter, M.S. (1973) The strength of weak ties. American Journal of Sociology, 78 (6), 1360-1380.

Gulati, R. (1999) Network location and learning; The influence of network resources and firm capabilities on alliance formation. Strategic Management Journal, 20, 397-420.

Harrison, R. T., Mason, C. M. and Girling, P. (2004) Financial bootstrapping and venture development in the software industry. Entrepreneurship \& Regional Development, 16 (4) 307 333 
Henard, D.H. and McFadyen, M.A. (2012) Resource dedication and new product performance: A resource-based view. Journal of Innovation Product Management, 29 (2), 193-204

Jack, S. (2005) The role, use and activation of strong and weak network ties: a qualitative analysis. Journal of Management Studies, 42 (6), 1233-1259.

Jones, O. and Jayawarna, D. (2010) Resourcing new businesses, social networks, bootstrapping and firm performance, Venture Capital, 12 (2) 127-152.

Karlsson, C. and Warda, P. (2014) Entrepreneurship and innovation networks. Small Business Economics, 43 (2) 393-398.

Kleinschmidt, E.J. de Brentani, U. and Salomo, S. (2007) Performance of global new product development programs: A resource-based view. Journal of Innovation Product Management, 21, 419-441

Knudson, W., Wysocki, A., Champagne, J. and Peterson, H.C. (2004) Entrepreneurship and innovation in the agri-food system. American Journal of Agricultural Economics, 86 (5), 13301336.

Lang, R., Fink, M. and Kibler, E. (2014) Understanding place-based entrepreneurship in rural Central Europe: A comparative institutional analysis. International Small Business Journal, 32 (2), 204-227.

Lawson, B. and Samson, D. (2001) Developing innovation capability in organisations: A dynamic capabilities approach. International Journal of Innovation Management, 5 (3), 377-400.

Löfqvist, L. (2017) Product innovation in small companies: Managing resource scarcity through financial bootstrapping. International Journal of Innovation Management, 21 (2) 1-27.

McKeever, E., Jack, S. and Anderson, A. (2015) Embedded entrepreneurship in the creative reconstruction of place. Journal of Business Venturing, 30 (1) 50-65.

McKelvey, B. (2004) Toward a complexity science of entrepreneurship. Journal of Business Venturing, 19, 313-341.

Miles, M. B., and Huberman, A. M. (1994) Qualitative data analysis: An expanded sourcebook (2nd ed.). Thousand Oaks, CA: Sage.

Morris, M.H., Kuratko, D.F., Schindehutte, M. and Spivack, A.J. (2012) Framing the entrepreneurial experience. Entrepreneurship Theory \& Practice, 36 (1), 11-40.

Newey, L. R., and Zahra, S. A. (2009) The evolving firm: How dynamic and operating capabilities interact to enable entrepreneurship. British Journal of Management, 20 (1), 81-100. 
North, D., Baldock, R. and Ullah, F. (2013). Funding the growth of UK technology-based small firms since the financial crash: Are there breakages in the finance escalator? Venture Capital, 15 (3), 237-260.

Oxley, L., Hong, S. and McCann, P. (2013) Beyond 'the beamer, the boat and the bach'? A content analysis-based case study of New Zealand innovative firms. Economics Working Paper no. 12/13. Hamilton: University of Waikato.

Parida, V. and Örtqvist, P. (2015) Interactive effects of network capability, ICT capability, and financial slack on technology-based small firm innovation performance. Journal of Small Business Management, 53 (S1), 278-298.

Patel, P. C., Flet, J. O., and Sohl, J. E. (2011) Mitigating the limited scalability of bootstrapping through strategic alliances to enhance new venture growth. International Small Business Journal, 29 (5), 421-427.

Patton, M. (2002) Qualitative Evaluation and Research Methods. London: Sage.

Peteraf, M.A. and Barney, J.B. (2003) Unravelling the resource-based tangle. Managerial and Decision Economics, 24 309-323

Plattfaut, R. Niehaves, B. Voigt, M. Malsbender, A. Ortbach, K. and Poeppelbuss, J. (2015) Service innovation performance and information technology: An empirical analysis from the dynamic capability perspective, International Journal of Innovation Management, 19 (4),

Politis, D. (2005) The process of entrepreneurial learning: A conceptual framework. Entrepreneurship Theory and Practice, 29 (4) 399-424.

Pratt, M. G. (2009) From the editors: For the lack of a boilerplate: Tips on writing up (and reviewing) qualitative research. Academy of Management Journal, 52 (5) 856-862.

Rae, D, and Carswell, M. (2001). Towards a conceptual understanding of entrepreneurial learning. Journal of Small Business and Enterprise Development, 8 (2) 150-158.

Rinnie, T.A. and Fairweather, J. (2011) An international comparison of models of innovation and their implications for New Zealand. Research Report no 323, August. Christchurch: Lincoln University.

Robinson, S. and Stubberud, H.A. (2012) Innovation networks in European small businesses. Proceedings of Academy of Studies in International Business, 12 (2) 1-6

Salvato, C., and Corbetta, G. (2013) Transitional leadership of advisors as a facilitator of successors leadership construction. Family Business Review, 26 (3), 235-255. 
Shamsuzzoha, A. and Kindi, M.A. (2016) Open innovation through virtual business network: Perspective from small and medium enterprises. Journal of IT and Economic Development, 7 (1) 25-33

Singh, N.P. and Stout, D.B. (2018) Knowledge flow, innovative capabilities and business success: Performance of the relationship between small world networks to promote innovation. International Journal of Innovation Management, 22 (2) 1-34.

Smallbone, D., North, D. and Kalantaridis, C. (1999) Adapting to peripherality: A study of small rural manufacturing firms in northern England. Entrepreneurship and Regional Development, 11 (2), 109-127.

Strauss, A. L. and Corbin, J. M. (1998) Basics of qualitative research: Techniques and procedures for developing grounded theory (2nd ed.) Thousand Oaks. CA: Sage

Svensson, P., Klofsten, M. and Etzkowitz, H. (2012) An entrepreneurial university strategy for renewing a declining industrial city: The Norrkőping way. European Planning Studies, 20 (4) 505-525.

Talaja. A. (2012). Testing VRIN framework: Resource value and rareness as sources of competitive advantage. Management, 17 (2) 51-64.

Teece, D.J. (1996) Firm organization, industrial structure and technological innovation. Journal of Economic Behavior and Organization, 31 (2) 193-225.

Teece, D.J. (2007) Explicating dynamic capabilities: The nature and microfoundations of (sustainable) enterprise performance. Strategic Management Journal, 28, 1319-1350.

Teece, D.J. (2009) Dynamic capabilities and strategic management. Oxford, OUP.

Teece, D.J. and Pisano, G. (1994).The dynamic capabilities of firms: An introduction. Industrial and Corporate Change, 3 (3) 537-556.

Thorpe, R., Gold, J., Holt, R. and Clarke, J. (2006) Immaturity: The constraining of entrepreneurship. International Small Business Journal, 24 (3), 232-252.

Virkkala, S. (2007) Innovation and networking in peripheral areas: A case study of emergence and change in rural manufacturing. European Planning Studies, 15 (4), 511-529.

Wang, C.L. and Chugh, H. (2014) Entrepreneurial learning: Past research and future challenges. International Journal of Management Reviews, 16 (1) 24-61.

Wang, K.Y., Hermens, A., Huang, K-P. and Chelliah, J. (2015) Entrepreneurial orientation and organizational learning on SMEs' innovation. The International Journal of Organizational Innovation, 4 71-81. 
Wernerfelt, B. (1984) A resource based view of the firm. Strategic Management Journal, 5 (2), 171-180.

Zahra, S. A. and George, G. (2002) Absorptive capacity: A review, reconceptualization, and extension. Academy of Management Review, 27 (2) 185-203.

Zahra, S.A. and Wright, M. (2011) Entrepreneurship's next act. Academy of Management Perspectives, 25 (4) 67-83. 
Table 1: Dynamic capabilities: Entrepreneurial learning and absorptive capacity

\begin{tabular}{|c|c|c|}
\hline $\begin{array}{l}\text { Case/ } \\
\text { Size in } \\
\text { FTEs/ } \\
\text { Respondent }\end{array}$ & Firm details/activity & Citation/interview data \\
\hline $\begin{array}{l}\neq 05 \\
\text { FTEs } 3 \\
\text { R=FE }\end{array}$ & $\begin{array}{l}\text { Effluent management service to } \\
\text { dairy farmers: } \\
\text { Entrepreneurial learning and } \\
\text { patient behaviour }\end{array}$ & $\begin{array}{l}\text { Yes we've had to change our approach, different parts of } \\
\text { our offering but that's as much because as you get into it } \\
\text { you learn more so you can never know everything when } \\
\text { you start. There is an element of learning by doing --It } \\
\text { was all completely new so you start off with a plan with } \\
\text { what you think you know those things are and it doesn't } \\
\text { go like you think which is about the only thing about a } \\
\text { plan you know is going to happen. }\end{array}$ \\
\hline $\begin{array}{l}\neq 16 \\
\text { FTEs } 3 \\
\mathrm{R}=\mathrm{FE}\end{array}$ & $\begin{array}{l}\text { Aborculture: } \\
\text { Entrepreneurial learning } \\
\text { Using networks } \\
\text { Patient behaviour. }\end{array}$ & $\begin{array}{l}\text { Trees, trees, knew nothing about trees., so there's that } \\
\text { knowledge in the horticulture industry and sort of } \\
\text { management background was really it--the first lot of } \\
\text { trees went overseas and they all died. So we had to go } \\
\text { through quite a learning process in terms of the } \\
\text { background to understand what happened and what we } \\
\text { have to change, what we need to do differently so there } \\
\text { was quite a, you know, quite a learning process. }\end{array}$ \\
\hline $\begin{array}{l}\text { FTEs } 9 \\
\text { R=MD }\end{array}$ & $\begin{array}{l}\text { Hydrophonics } \\
\text { Entrepreneurial learning Patient } \\
\text { behaviour }\end{array}$ & $\begin{array}{l}\text { In terms of technology it has evolved a lot over time as } \\
\text { (name) learnt more and more about not only hydroponic } \\
\text { growing, but climate control inside a greenhouse and then } \\
\text { of course farmers are more than happy to come up with } \\
\text { their own requirements and they all do seem to operate } \\
\text { quite differently, so very often you would find he would } \\
\text { go to implement a solution and they would say oh it } \\
\text { would be great if it could do this and you say you are } \\
\text { right it would be. And he was always up for the technical } \\
\text { challenge and so he did find that we spent a lot of time on } \\
\text { R\&D being the evolution of controllers. There was } \\
\text { several dosing type controllers that went through a mark } \\
\text { one, mark two version three typo scenario just as he } \\
\text { became more familiar with both hydroponics and the } \\
\text { needs of the growers. }\end{array}$ \\
\hline $\begin{array}{l}\text { FTEs } 9 \\
\text { R+FE }\end{array}$ & $\begin{array}{l}\text { New fruit grower and producer } \\
\text { Entrepreneurial learning Patient } \\
\text { behaviour } \\
\text { Local investors }\end{array}$ & $\begin{array}{l}\text { We've been playing around with that space for a long } \\
\text { time, so we're not new to exporting but we're exclusively } \\
\text { (new product brand) now. It was my company and I did } \\
\text { an angel investors' pitch and got the new shareholders in, } \\
\text { because I'd taken it as far as I could go myself. It was } \\
\text { long winded, it was a hell of a lot more involved than } \\
\text { what I thought it would be, but I think the benefits far } \\
\text { outweigh the negatives. All are enterprise angels which is } \\
\text { Tauranga based, all of them. } \\
\text { What I started doing was spending a lot of time going } \\
\text { around retailers, both in New Zealand and offshore, I } \\
\text { went offshore and I picked up on the confectionary } \\
\text { business which in late } 2008 \text {--, was really thumping the } \\
\text { fruit produce industry, and I noticed what they were } \\
\text { doing was downsizing their offerings, -- I picked up that } \\
\text { what they were doing -- so that's where I decided that hey } \\
\text { this is where the real opportunity of this thing is, now I } \\
\text { need to find a vessel or a delivery and that's going to be }\end{array}$ \\
\hline
\end{tabular}




\begin{tabular}{|c|c|c|}
\hline & & my point of difference. \\
\hline $\begin{array}{l}\neq 30 \\
\text { FTEs } 11 \\
\text { R=FE }\end{array}$ & $\begin{array}{l}\text { Biotech } \\
\text { 'Born global' } \\
\text { Entrepreneurial learning } \\
\text { Patient behaviour }\end{array}$ & $\begin{array}{l}\text { We started doing that and we did that quite happily for a } \\
\text { number of years, we began to look up the value chart and } \\
\text { we found that the tissue that we were taking from these } \\
\text { cows that we were selling at the time for } \$ 100 \text { a } \\
\text { kilogram, if you extracted the proteins from them which } \\
\text { is called collagen, you could sell that for much more } \\
\text { money, so you could sell that for } \$ 50 \text { or } \$ 60,000 \text { per kilo, } \\
\text { now ok it takes more than } 1 \text { kilogram to get, so it's about } \\
\text { ten to one, but even ten to one it's still fine, there's a huge } \\
\text { difference, so we set up about } 4 \text { years ago, we } \\
\text { investigated, raised the money and set up a factory to } \\
\text { process this tissue to extract the collagen, extract the } \\
\text { proteins, and sell that to device companies--we're selling } \\
\text { them the extracted proteins and so that is a different } \\
\text { business and quite a different business model. } \\
\text { We only have one independent director, and he's a guy } \\
\text { that's made a few hundred million and he's a great coach, } \\
\text { his view is just make sure the base is solid, your next base } \\
\text { is solid because you may have to retreat to that base, you } \\
\text { know if you step out and it doesn't work you want to be } \\
\text { able to retreat to that, and so we're probably still } 18 \\
\text { months away from the next leap. We learned the hard } \\
\text { way, the medical device, the table manners in the medical } \\
\text { device industry is something to be desired, what people } \\
\text { will do, you really have to be very careful and much more } \\
\text { careful than you would in a lot of trades-----I think that's } \\
\text { been our main learning } \\
\text { The other learning is getting reliable market information } \\
\text { is incredibly difficult, and you're never going to have } \\
\text { perfect information, (we have) been working on it for } 18 \\
\text { months, you know to really capture all of the players } \\
\text { internationally who are using bovine collagen in their } \\
\text { medical device, ----- so I guess we've learned that we } \\
\text { had, market data is hard to get but you need to invest and } \\
\text { work at it. }\end{array}$ \\
\hline
\end{tabular}

Key

\begin{tabular}{|l|l|}
\hline \multicolumn{2}{|c|}{$\mathrm{R}=$ Respondent } \\
\hline FE & Founding entrepreneur \\
\hline MD & Managing director \\
\hline
\end{tabular}


Table 2: Dynamic capabilities: Using networks

\begin{tabular}{|c|c|c|}
\hline $\begin{array}{l}\text { Case/ } \\
\text { Size in } \\
\text { FTEs/ } \\
\text { Respondent }\end{array}$ & Firm details/activity & Citation/interview data \\
\hline $\begin{array}{l}\text { FTEs } 3 \\
\text { R+FE }\end{array}$ & $\begin{array}{l}\text { Established for three } \\
\text { years, the company } \\
\text { provides an information } \\
\text { management service for } \\
\text { the dairy industry and } \\
\text { specialises in effluent } \\
\text { control. } \\
\text { Using networks } \\
\text { Customers as early } \\
\text { adopters }\end{array}$ & $\begin{array}{l}\text { You know I belong to group of women founders of tech businesses } \\
\text { and so within that group we -you know somebody knows a } \\
\text { developer who's available, or they have done some contract work } \\
\text { for them, and they will tend to be smaller business so there is that } \\
\text { sort of sharing of resources and knowledge and there's probably all } \\
\text { sorts of little pockets like that - it's been going for about six } \\
\text { months and it's been certainly clear, as with the more times we } \\
\text { meet and talk about things [...] the experiences and the challenges } \\
\text { are different for women and when you get together as a group; a } \\
\text { group of women actually exchange information in quite a different } \\
\text { way than a mixed group. } \\
\text { The other strategy we have is really trying to use - because the } \\
\text { majority of our customers we know are early adopters and are } \\
\text { recognised as such in their communities - to actually use them as } \\
\text { the centre of the sale and to actually focus their bits on working out } \\
\text { from there, because farmers sell to farmers, so they like to be able } \\
\text { to go and talk to someone who has got it. }\end{array}$ \\
\hline $\begin{array}{l}\text { FTEs } 7 \\
\text { R=FE }\end{array}$ & $\begin{array}{l}\text { Irrigation systems: } \\
\text { Patient behaviour } \\
\text { Pragmatic action } \\
\text { Using networks }\end{array}$ & $\begin{array}{l}\text { I guess I have been involved in the industry for } 10 \text { or } 12 \text { years, it's } \\
\text { just utilisation of those networks I guess - so some people probably } \\
\text { see the business and think that it's had huge growth and it's } \\
\text { accelerated growth, but it's a result of } 10 \text { or } 12 \text { years of networking } \\
\text { within the industry and then sort of pulling all that together in a } \\
\text { short time which is what we have been able to do. } \\
\text { So I guess just, we had pretty big ambitions about what we were } \\
\text { going to do and how we were going to do it ---so, after committing } \\
\text { to quite a few overheads- it was pulling back to basics and just } \\
\text { bread and butter stuff which was irrigation and effluent. ---So, what } \\
\text { I am probably keen to do is just keep consolidating at this level and } \\
\text { maintain efficiencies within and just try and keep control of it, } \\
\text { because it's enjoyable at the moment,--- but it's just a result of } 10 \\
\text { or } 12 \text { years of networking within the industry and then sort of } \\
\text { pulling all that together in a short time which is what we have been } \\
\text { able to do. }\end{array}$ \\
\hline $\begin{array}{l}\neq 25 \\
\text { FTEs } 4 \\
\text { R+FE }\end{array}$ & $\begin{array}{l}\text { Effluent control } \\
\text { Using feedback from a } \\
\text { close network of farmers } \\
\text { as customers }\end{array}$ & $\begin{array}{l}\text { We've actually got an ad in this month's Dairyman, it's referring to } \\
\text { these dairy businesses of the year, and how their effluent storage } \\
\text { has brought them up to ..., capital and milk solids have sort of } \\
\text { doubled through storage, a grudge payment but it's about the } \\
\text { environment then ... when it all started because we were the only } \\
\text { company doing gas drainage and water drainage under the ponds, } \\
\text { we were leaving the water drainage as optional, most of the other } \\
\text { companies are still like that with their gas and the water, but I } \\
\text { quickly realised to make that not optional, they have to have it } \\
\text { otherwise they aren't going to last, you'd be surprised some of the } \\
\text { huger companies are not up to that point. }\end{array}$ \\
\hline
\end{tabular}

Key

$\mathrm{R}=$ Respondent

\begin{tabular}{l|l}
\hline FE & Founding entrepreneur
\end{tabular} 
Table 3: Dynamic capabilities: Pragmatic action-based solutions

\begin{tabular}{|c|c|c|}
\hline $\begin{array}{l}\text { Case/ } \\
\text { Size in } \\
\text { FTEs/ } \\
\text { Respondent }\end{array}$ & Firm details/activity & Citation/interview data \\
\hline $\begin{array}{l}\neq 01 \\
\text { FTEs } 16 \\
\text { R=FE }\end{array}$ & $\begin{array}{l}\text { Engineering and manufacturer } \\
\text { of farm equipment: } \\
\text { Customer co-creation }\end{array}$ & $\begin{array}{l}\text { Because that's we learnt how all of our products have come } \\
\text { about is because we install them and then watch them and then } \\
\text { work with customer when they break or when and they are } \\
\text { obviously that, when they are very successful you can go and } \\
\text { check it all the time and find out why. }\end{array}$ \\
\hline $\begin{array}{l}\text { FTEs } 65 \\
\text { R=NPD }\end{array}$ & $\begin{array}{l}\text { Engineering and earth moving } \\
\text { equipment: } \\
\text { Dynamic capabilities and } \\
\text { patient behaviour }\end{array}$ & $\begin{array}{l}\text { The senior management team has been together for } 6 \text { years and } \\
\text { we purposefully put that team together to enable us to grow the } \\
\text { company. We wanted good strengths and capabilities around } \\
\text { us to enable us to do that. } \\
\text { From a knowledge perspective,--- my brother and I haven't } \\
\text { done anything else other than be in the quick coupler field for } \\
\text { the last } 25 \text { years, so as far as our experience and understanding } \\
\text { of trends and where it's going, I would say there wouldn't be } \\
\text { too many people around that would know as much as we do, } \\
\text { because we travel a lot to trade shows and we have a lot of } \\
\text { good networks through the industry at all levels, so from that } \\
\text { perspective I'd say there aren't any gaps. From a capability } \\
\text { perspective in the engineering side there's always room for } \\
\text { more people. }\end{array}$ \\
\hline $\begin{array}{l}\text { FTEs } 12 \\
\mathrm{R}=\mathrm{MD}\end{array}$ & $\begin{array}{l}\text { IT applied to testing in stock } \\
\text { farming: } \\
\text { Using customer feedback and } \\
\text { co-creation }\end{array}$ & $\begin{array}{l}\text { The area sales managers, their role is really important, not only } \\
\text { as sales people, but their role is also to interact with the } \\
\text { customers, my role ---is to do much the same, but on a more } \\
\text { technical level. We have support service, area sales people, we } \\
\text { have field service technicians, we have the marketing side } \\
\text { which makes sure we're touching base with the customers, we } \\
\text { have newsletters and texting service. We've also got a number } \\
\text { of large corporate farmer relationships, so there's relationships } \\
\text { at farm manager level and then at the corporate farmer level. }\end{array}$ \\
\hline $\begin{array}{l}\text { FTEs } 43 \\
\text { R=FE }\end{array}$ & $\begin{array}{l}\text { Manufacture of farm } \\
\text { equipment: } \\
\text { Pragmatic solution and } \\
\text { stretching resources }\end{array}$ & $\begin{array}{l}\text { So that's one of my principles roles here is to improve our } \\
\text { production flow and improve what we can do with what we've } \\
\text { got, so we've seen some fairly large changes over the last few } \\
\text { years, we've just built a 400sqm shed out the back to help } \\
\text { alleviate that issue, but already that's proving to be not } \\
\text { enough, they need more, but then on the flipside of that if we } \\
\text { did move, our options would be to move to New Plymouth, } \\
\text { then that becomes too costly. We've got a great labour force, } \\
\text { young guys off the farm, great work ethic, ready to work long } \\
\text { hours and hard, and enjoy it without grumbling, it's unique. }\end{array}$ \\
\hline $\begin{array}{l}\text { FTEs } 8 \\
\text { R=NPD }\end{array}$ & $\begin{array}{l}\text { Remote telemetry } \\
\text { Pragmatic action through } \\
\text { customer feedback } \\
\text { Bootstrapping }\end{array}$ & $\begin{array}{l}\text { Two years R \& D for the cell modem, we have had a few } \\
\text { applications with these, we used this along with probes, } \\
\text { temperature probes and, basically, we have them monitoring } \\
\text { the ice cream trucks, so we had a few test cases where the ice } \\
\text { cream truck drivers would like to know whether or not the } \\
\text { product was okay or not. } \\
\text { We have three trial sites, one is Satara, we first started } \\
\text { developing this with collaboration with Satara because I think }\end{array}$ \\
\hline
\end{tabular}




\begin{tabular}{|c|c|c|}
\hline & & $\begin{array}{l}4 / 5 \text { years ago Satara was having massive losses in their kiwi } \\
\text { fruit industry and because the product was not being monitored } \\
\text { properly so we decided to develop this gear in collaboration } \\
\text { with them so that they could manage and monitor their cool } \\
\text { stores. After that, we moved on and we started making the } \\
\text { product more mature, we got other trial sites, so they have } \\
\text { their own network there as well and we are their monitoring, } \\
\text { we actually saved them quite a bit of money because they had } \\
\text { a couple of power failures. Everything was built from scratch } \\
\text { because had troubles with the temperature range because it's } \\
\text { really sensitive, it's accurate to about }+ \text { or - } .3 \text { degrees and it } \\
\text { has quite a broad range of temperature it can go from }-40 \text { to } \\
+100 \text {. } \\
\text { At the start we had } 3 \text { to } 4 \text { people working on this product and } \\
\text { developing it from scratch and eventually as the time went on } \\
\text { and people moved on it got down to just one person } \\
\text { developing this and maturing this product because the rest of } \\
\text { the company was-- too busy doing solutions to keep the } \\
\text { company alive. So basically the solution side would then } \\
\text { bootstrap the apri side so we could still put some money in. }\end{array}$ \\
\hline $\begin{array}{l}\neq 24 \\
\text { FTEs } 31 \\
\text { R=MD }\end{array}$ & $\begin{array}{l}\text { Water technology (shower and } \\
\text { tap manufacturer, applications } \\
\text { to farmers and agri-business) } \\
\text { Pragmatic actions } \\
\text { Building reputation }\end{array}$ & $\begin{array}{l}\text { Because I'd had a farming background as a little kid I thought } \\
\text { about Christmas last year why don't we do with yard wash } \\
\text { because I know that effluent management on farms is a hot } \\
\text { topic, it was in the paper a lot last year, --- so we got onto a } \\
\text { farm in South Auckland in January/February of this year and } \\
\text { started trialling some concept models of a nozzle that pulled } \\
\text { air in the side --and found that the farmer was saving around } \\
30 \% \text { of his waterflow. } \\
\text { We're running a trial now of } 30 \text { farms from Taupo to } \\
\text { Northland and we've outfitted their yards with water meters } \\
\text { and that's where a lot of the cost has come in, it's paying } \\
\text { plumbers to go out and set up the yards and we've just 3D } \\
\text { printed } 30 \text { sets of nozzles with various things the guys can } \\
\text { change. } \\
\text { They made some claims and really we wanted to check out } \\
\text { what they had and to be able to do that we needed a contact } \\
\text { with them and then they gave us the prototypes and we were } \\
\text { getting } 50 \% \text { to } 60 \% \text { savings in terms of water volume and then } \\
\text { what we got from them when we put it on an apples for apples } \\
\text { system was less, but the idea of making aeration and showers } \\
\text { is nothing new, there are lots of companies that have used } \\
\text { aeration in showers to different effects, from engineering } \\
\text { perspective we were using aeration to try and increase the } \\
\text { velocity of the flow. Our point of difference is that we have a } \\
\text { very good reputation in the industry, we are weak on product } \\
\text { aesthetics,---but I think our strength is I'd say from a purely } \\
\text { retail perspective we're probably ranked at brand number } 10 \\
\text { out of } 100 \text { brands in NZ but from a trade perspective we would } \\
\text { be ranked as brand number } 2 \text { out of } 100 \text { brands in NZ }\end{array}$ \\
\hline
\end{tabular}

Key

\begin{tabular}{|l|l|}
\hline \multicolumn{2}{|c|}{$\mathrm{R}=$ Respondent } \\
\hline FE & Founding entrepreneur \\
\hline NPD & New product development manager \\
\hline MD & Managing director \\
\hline
\end{tabular}


Table 4: Patient behaviour

\begin{tabular}{|c|c|c|}
\hline $\begin{array}{l}\text { Case/ } \\
\text { Size in } \\
\text { FTEs/ } \\
\text { Respondent }\end{array}$ & $\begin{array}{l}\text { Firm } \\
\text { details/activity }\end{array}$ & Citation/interview data \\
\hline $\begin{array}{l}\text { FTEs } 30 \\
\text { R=FE }\end{array}$ & $\begin{array}{l}\text { Manufacturer of calf- } \\
\text { feeding equipment: } \\
\text { Pragmatic and patient } \\
\text { solution to gaining } \\
\text { customers }\end{array}$ & $\begin{array}{l}\text { I do probably the opposite to what a lot of New Zealanders do, they } \\
\text { go overseas, set up a trade fair and wait for people to come to them, } \\
\text { whereas I go to the trade fairs and pick my customer, and say would } \\
\text { you like to sell my product and that way you know how big they are, } \\
\text { you know what they're already selling and hopefully they'll pick up } \\
\text { your product. }\end{array}$ \\
\hline $\begin{array}{l}\text { FTEs } 30 \\
\text { R=FM }\end{array}$ & $\begin{array}{l}\text { Software programming } \\
\text { for farmers: } \\
\text { Patient development } \\
\text { working with } \\
\text { customers and } \\
\text { institutions }\end{array}$ & $\begin{array}{l}\text { While things have grown in the last } 3 \text { years, there's been } 27 \text { years } \\
\text { behind that, it's always nice to be working with a well-established } \\
\text { brand, so I think that's one of the big advantages that we have, ---one } \\
\text { of the things we've worked on in the last } 3 \text { years, is we work more } \\
\text { with accountants. Originally it was all about the farmers, but we're } \\
\text { actually engaging more of the accountants, we're engaging a lot with } \\
\text { the banks at the moment as you can see from our latest newsletter, } \\
\text { we're doing work with ANZ and we have done work with National } \\
\text { Bank in the past. }\end{array}$ \\
\hline $\begin{array}{l}\text { FTEs } 3 \\
\mathrm{R}=\mathrm{FE}\end{array}$ & $\begin{array}{l}\text { Dairy farm equipment: } \\
\text { Patient development } \\
\text { and working with } \\
\text { customers. } \\
\text { Entrepreneurial } \\
\text { learning }\end{array}$ & $\begin{array}{l}\text { We started (the company) about } 7 \text { years ago and (we) grew out of that } \\
\text { business. -- We had a really few keen (farmers) that liked the idea } \\
\text { very early on and they were happy enough to pay for the prototypes } \\
\text { which was quite nice. It's been a long on-going process we were a bit } \\
\text { late in the process going to the (EDA) to try and get the grants, but } \\
\text { we've been in talks with them with other projects.-- We had a lot of } \\
\text { problems early on if it wasn't the electronics it was the mechanics of } \\
\text { it, it took quite a while to refine. It was like anything the first thing } \\
\text { you develop, we were doing everything from scratch and we did learn } \\
\text { a lot with the first one. }\end{array}$ \\
\hline $\begin{array}{l}\text { FTEs } 18 \\
\mathrm{R}=\mathrm{FE}\end{array}$ & $\begin{array}{l}\text { Remote telemetry } \\
\text { Patient behaviour, } \\
\text { bootstrapping and } \\
\text { customer feedback }\end{array}$ & $\begin{array}{l}\text { And so I grew out of (the company's) earnings, I never borrowed to } \\
\text { grow and it meant that I grew a bit slower than some companies, but } \\
\text { it meant that if anything went wrong, I wasn't going to lose my house } \\
\text { and I wasn't going to lose my shirt. After I got the [...] contract, a } \\
\text { merchant banker came to me and said -- you need five million dollars } \\
\text { or something, and I said 'no I'm not interested'. }\end{array}$ \\
\hline $\begin{array}{l}\text { FTEs } 12 \\
\text { R+FE }\end{array}$ & $\begin{array}{l}\text { Fertiliser and seed } \\
\text { technology: } \\
\text { Patient behaviour and } \\
\text { using customer } \\
\text { feedback }\end{array}$ & $\begin{array}{l}\text { So we've always been very mindful to grow the business. We needed } \\
\text { to have a machine first that would do the business all day, every day, } \\
\text { without any problems, so we had a reliable technology. That's been } \\
\text { the first, I suppose, hurdle we've had to overcome which we did with } \\
\text { the help of (a grant) which is fantastic and lots of field testing was } \\
\text { done on that. Then it was looking to developing a client base that we } \\
\text { could fill with that technology and now that we're getting the referral, } \\
\text { and more business is coming up, the challenge is to weigh up our } \\
\text { capacity with new business, so we are very mindful that we want this } \\
\text { to be successful and we don't want over promise and under deliver. }\end{array}$ \\
\hline $\begin{array}{l}\text { FTEs } 4 \\
\text { R=FE }\end{array}$ & $\begin{array}{l}\text { Dairy bio-technology } \\
\text { company } \\
\text { Patient behaviour } \\
\text { Pragmatic action } \\
\text { Bootstrapping } \\
\text { Local investors }\end{array}$ & $\begin{array}{l}\text { From the time we started [the company], we knew we had to get some } \\
\text { investors on board. My co-founder and I, we had a little bit of seed } \\
\text { funding that we had put into it, but right away we started looking for } \\
\text { an angel investor group - we were looking for } \$ 200 \mathrm{k} \text { mainly to get } \\
\text { some early pilot skilled studies done in mastitis and to get some sales } \\
\text { efforts going in human health. It ended up taking us two years, so we } \\
\text { ended up funding it a lot longer than we had planned, but it didn't }\end{array}$ \\
\hline
\end{tabular}




\begin{tabular}{|c|c|c|}
\hline & & $\begin{array}{l}\text { grow as nearly as quickly as we had hoped because we had limited } \\
\text { funding. We finally secured a local group of investors along with the } \\
\text { New Zealand SCIF Scheme }{ }^{\mathrm{i}} \text {. We've had them on board for } 2 \frac{1}{2} \mathrm{years} \text {, } \\
\text { there are five individual investors that formed an investment vehicle } \\
\ldots \text { in the end they came back and it's been great because they are } \\
\text { local, they are a good group of businessmen - really helpful around } \\
\text { the board table focussing the human health applications down and we } \\
\text { all have similar end points in mind. }\end{array}$ \\
\hline $\begin{array}{l}\text { FTEs } 6 \\
\text { R=FE }\end{array}$ & $\begin{array}{l}\text { Biotech applied to } \\
\text { forestry: } \\
\text { Long term patient } \\
\text { behaviour } \\
\text { Entrepreneurial } \\
\text { learning }\end{array}$ & $\begin{array}{l}\text { Being a bio technology business, the first challenge was to get the } \\
\text { material and production systems going so that involved two things, } \\
\text { one is to get the clones through a sematic embryo genesis process, a } \\
\text { tissue culture process, cryo store them and then a period of field } \\
\text { testing in client trials, which takes years to accomplish with forest } \\
\text { trees, and parallel with that we have been developing a production } \\
\text { system to more efficiently develop the clonal plants, because they } \\
\text { have to start from a deep frozen condition and basically have to be } \\
\text { multiplied up through several stages --so we've tested over } 1,000 \text { and } \\
\text { we've selected about } 20 \text { that we use. } \\
\text { The forest industry is cost averse and conservative by nature and } \\
\text { when you are dealing with genetic improvement you are dealing with } \\
\text { a } 30 \text { year time horizon plus from the sale of our product to the } \\
\text { realisation of the benefit in the plantation, so, not too surprisingly, } \\
\text { there's a lot of discounting of value goes on from } 30 \text { years out back to } \\
\text { the present so we have to make a very strong case with the } \\
\text { improvements that we make. } \\
\text { We are not working with one technology we're working with } \\
\text { probably } 20 \text { different technologies to go from the point of the frozen } \\
\text { tree all the way through to the product so we've just made } \\
\text { incremental improvements in efficiencies and yields just by learning } \\
\text { how to do this stuff. }\end{array}$ \\
\hline $\begin{array}{l}\text { FTEs } 25 \\
\text { R=GM }\end{array}$ & $\begin{array}{l}\text { Manufacturer of } \\
\text { agricultural equipment } \\
\text { (mowers and other } \\
\text { equipment). Long } \\
\text { established family } \\
\text { business taken over by } \\
\text { a group of local } \\
\text { investors. } \\
\text { Patient behaviour }\end{array}$ & $\begin{array}{l}\text { Longevity gives you good roots in the business and good roots with } \\
\text { your customers. There's always a lack of resources, we could do } \\
\text { things quicker and faster with more but then you've got financial } \\
\text { constraints too. We could always use more resources and that's what } \\
\text { I'm saying, there's always a gap but it comes down to how wide are } \\
\text { your shoulders and whether you push the shoulders together to fill the } \\
\text { gap and how hard you can push, but it's pretty rare that a business } \\
\text { structure or model can run on full resources with no gaps. }\end{array}$ \\
\hline $\begin{array}{l}\text { FTEs } 2 \\
\mathrm{R}=\mathrm{FE}\end{array}$ & $\begin{array}{l}\text { Biotech, waste } \\
\text { treatment } \\
\text { Very small family } \\
\text { business } \\
\text { Patient behaviour } \\
\text { Customer feedback }\end{array}$ & $\begin{array}{l}\text { We've been around about } 11 \text { years, but we were mainly doing the } \\
\text { waste tanks at first, we found other uses for the same product, then } \\
\text { about } 3 \text { years ago we got introduced, also from a small family } \\
\text { business in America, and the guy is a bit like a mad professor and he } \\
\text { used to say things, he comes out with these amazing things and you } \\
\text { think that's not possible, but you try it and it works. } \\
\text { We also found that adding certain things to the product changes the } \\
\text { way it works and makes it better, we've actually improved on it. The } \\
\text { original product that we got, they weren't aware that it did anything } \\
\text { like in the soil for example, and we discovered that, we found that it } \\
\text { did and in certain other things. We've got some corn trials, we did } \\
\text { some trials on maize and we got something like a } 30 \% \text { increase, so } \\
\text { not small and the grass, this guy his grass he sat there with a plate } \\
\text { meter, and he'd taken some readings when we went out to this farm I } \\
\text { was telling you about with the three strips. We get lots of feedback, } \\
\text { like the cows eat the grass the next day after spraying. }\end{array}$ \\
\hline$\neq 27$ & Animal tags & The innovation is the metal tags, but also in the "applicator". The \\
\hline
\end{tabular}




\begin{tabular}{|c|c|c|}
\hline $\begin{array}{l}\text { FTEs } 80 \\
\text { R=FE }\end{array}$ & $\begin{array}{l}\text { Long established } \\
\text { founded in } 1991 \\
\text { Patient and paced } \\
\text { development } \\
\text { (internally funded, } \\
\text { started from sales in } \\
\text { US) }\end{array}$ & $\begin{array}{l}\text { applicator is special and is made with a high regard for health and } \\
\text { safety both for the animal and for the farmer. There has been } \\
\text { continuous innovation through re-investment and we hold global } \\
\text { patents which are very important. Our advantages lie in our } \\
\text { knowledge, experience and reputation for being an innovative } \\
\text { company. ---We are the only NZ-owned company that make animal } \\
\text { tags, but most people would not recognise us as such. New customers } \\
\text { are from word-of-mouth and recommendations, but also from } \\
\text { newsletters and 'events' such as field days and exhibitions. Our } \\
\text { reputation has been built over time and has been hard-earned. }\end{array}$ \\
\hline
\end{tabular}

Key

\begin{tabular}{|l|l|}
\hline \multicolumn{2}{|c|}{$\mathrm{R}=$ Respondent } \\
\hline FE & Founding entrepreneur \\
\hline FM & Financial manager \\
\hline GM & General manager \\
\hline
\end{tabular}


Table 5: Bootstrapping and bricolage

\begin{tabular}{|c|c|c|}
\hline $\begin{array}{l}\text { Case/ } \\
\text { Size in } \\
\text { FTEs/ } \\
\text { Respondent }\end{array}$ & Firm details/activity & Citation/interview data \\
\hline $\begin{array}{l}\text { FTEs } 25 \\
\mathrm{R}=\mathrm{FE}\end{array}$ & $\begin{array}{l}\text { Fertiliser analysis and } \\
\text { service to farmers: } \\
\text { Stretching limited finance } \\
\text { with pragmatic action }\end{array}$ & $\begin{array}{l}\text { So that would be number one thing that's limited us, I guess access } \\
\text { to required funding and that comes back to the monetary thing with } \\
\text { the level of growth we've experienced, then doing a lot of R\&D -- } \\
\text { has maybe limited our ability to spend the required funds to do } \\
\text { some very detailed research to validate some of the benefits being } \\
\text { achieved on farm. Second most common comment received from } \\
\text { farmers, which does link in to the first one a little bit, but we do get } \\
\text { a bit of resistance around price, per unit of nutrient applied to the } \\
\text { soil, our system will be more expensive than a standard fertiliser } \\
\text { system, but if we were able to validate some of the improvements } \\
\text { and productivity or profitability, ---I guess the correct balance of } \\
\text { nutrients, as in when required on the property, we could start to } \\
\text { show or validate the economic benefits, so from what you're } \\
\text { spending dollars on fertiliser per year, with the increased } \\
\text { productivity being achieved from that, being able to validate that } \\
\text { and allow the farmers to see there's an economic benefit }\end{array}$ \\
\hline $\begin{array}{l}\neq 04 \\
\text { FTEs } 1 \\
\text { R=FE }\end{array}$ & $\begin{array}{l}\text { Early stage small } \\
\text { company with prototype } \\
\text { for a stock feeding } \\
\text { system: } \\
\text { Pragmatic bootstrapping } \\
\end{array}$ & $\begin{array}{l}\text { It's been going on for about three years and my last two years, } \\
\text { when I worked in Palmerton, this was part-time so my previous } \\
\text { incomes have sort of funded the development but I registered this } \\
\text { company about } 18 \text { months ago and I've been full time at it since } \\
\text { November last year (about } 10 \text { months) }\end{array}$ \\
\hline $\begin{array}{l}\text { FTEs } 20 \\
\mathrm{R}=\mathrm{FE}\end{array}$ & $\begin{array}{l}\text { Manufacturing: } \\
\text { Bootstrapping }\end{array}$ & $\begin{array}{l}\text { It started off just with two or three of us, for many years it just self- } \\
\text { funded itself really up until to 2000, ---but we were already one of } \\
\text { the first in New Zealand to put robots in, ---but we wanted to get } \\
\text { into laser cutting, so we did and did some massive jobs in the early } \\
\text { days, --and when we drew it up to putting four lasers in we had the } \\
\text { most in New Zealand in } 2008,-- \text {-so then we grew the cutting } \\
\text { business-- then in January last year we put the world's fastest laser } \\
\text { in and we got it updated and now we have the most powerful and } \\
\text { the fastest fibre laser cutter in Australasia, and that gives us really } \\
\text { leaps and bounds above anyone else. (We) develop, manufacture, } \\
\text { do a lot of prototyping, like the trailer coupling, that's what the } \\
\text { company was founded on, we still make more trailer couplings } \\
\text { today than we did } 25 \text { years ago, it's huge and our business is still } \\
\text { growing-- we sell all over the world--Growth through internal } \\
\text { investment, --the only way to grow the business was by investing } \\
\text { heavily in new machinery and new products and new ways of doing } \\
\text { it, it's worked very well for us. }\end{array}$ \\
\hline$\neq 12$ & $\begin{array}{l}\text { Flax oil processing: } \\
\text { Bootstrapping } \\
\text { Bricolage } \\
\text { Entrepreneurial learning }\end{array}$ & $\begin{array}{l}\text { Our biggest problem we have is that we cannot compete in that } \\
\text { lower end market because our raw material is too expensive, but we } \\
\text { have looked at that --and our biggest investment is being a faster, } \\
\text { bigger processing facility that we made mobile to be able to get our } \\
\text { cost of production down to make us more competitive.---That was } \\
\text { our wee project a couple of years ago and it was frustrating slightly } \\
\text { because --- we now understand more about what funding we could } \\
\text { get, but at that point we had no idea we could get funding for }\end{array}$ \\
\hline
\end{tabular}




\begin{tabular}{|c|c|c|}
\hline $\begin{array}{l}\text { FTEs } 8 \\
\text { R=FE }\end{array}$ & & $\begin{array}{l}\text { anything so we developed this and it cost us a lot of money.-- It was } \\
\text { a big investment. } \\
\text { The idea was to be able to take it to the grower because a couple of } \\
\text { years ago there was the concern are we going to be able to get } \\
\text { enough raw material from Canterbury whereas potentially we could } \\
\text { get growers from the North Island so with this machine we could } \\
\text { drive up there and process it and press it all up in the North Island. } \\
\text { We are a small team and ---probably, from the manufacturing point } \\
\text { of view, we have learnt quite a lot about certain bits of equipment } \\
\text { that aren't working. But once again that's been a trial and error and } \\
\text { even from our mobile, from our large expellers, it's been an } \\
\text { interesting, we've got it all built and it didn't work so it took us } 6 \\
\text { months to get it to work -- in the weekends stripping machines } \\
\text { down and rebuilding them, because this equipment is unique and } \\
\text { even unique from the other people that are our competitors there is } \\
\text { no advice on the technology and, if it is, it is all in a language you } \\
\text { can't understand. }\end{array}$ \\
\hline $\begin{array}{l}\text { FTEs } 3 \\
\mathrm{R}=\mathrm{FE}\end{array}$ & $\begin{array}{l}\text { Vanilla processing: } \\
\text { Bootstrapping through } \\
\text { using internal resources } \\
\text { and leverage with } \\
\text { partnerships. }\end{array}$ & $\begin{array}{l}\text { Well they largely work on campus because of the equipment that } \\
\text { they need to use like a mass spectrum analysis type equipment, } \\
\text { which is quite expensive, but the university already had it apart } \\
\text { from this extra one piece of equipment to support what we are } \\
\text { trying to do. } \\
\text { So what happened was we brought our first harvest back from } \\
\text { Tonga, it was quite small, it was only like two boxes and we } \\
\text { actually brought them back as hand luggage, we had some contacts } \\
\text { in Auckland, we managed to quite early on connect with some quite } \\
\text { high profile chefs which a lot of our marketing is based on } \\
\text { relationships with top chefs and their endorsements --so that sort of } \\
\text { gave us some confidence and when he gave us that feedback we } \\
\text { thought well we've only got these two boxes so if we are going to } \\
\text { give them to anyone we might as well give them to all the top } \\
\text { chefs, so we basically went on the road and we would go and have } \\
\text { a meal in a restaurant and then tackle the chef afterwards.--- } \\
\text { We started working with a local food technologist here in Tauranga } \\
\text { and we paid her for like } 10 \text { hours and she basically, was great, she } \\
\text { mapped out, she did like this big mind map of everything we were } \\
\text { going to have to tackle and what food technology was all about } \\
\text { because neither of us had been in food before. }\end{array}$ \\
\hline $\begin{array}{l}\text { FTEs } 18 \\
\mathrm{R}=\mathrm{MD}\end{array}$ & $\begin{array}{l}\text { Aerial surveys and } \\
\text { photography } \\
\text { Bootstrapping } \\
\text { Making the resources } \\
\text { work }\end{array}$ & $\begin{array}{l}\text { We obviously make our assets work and I think we have some } \\
\text { advantages in the way we tackle projects and process them after } \\
\text { we've captured them---we still manage to compete very well so we } \\
\text { have to have some efficiencies which must be in our back end } \\
\text { processing. } \\
\text { We're also putting in these engine special nozzles in the fuel } \\
\text { management system, which allow us to run the engine it's called } \\
\text { lean of peak, so we can save } 20 \% \text { on our fuel bill for most of the } \\
\text { stuff that plane would do, most of the work that aircraft would do, } \\
\text { so they're not new to market. }\end{array}$ \\
\hline $\begin{array}{l}\text { FTEs } 35 \\
\text { R=NPD }\end{array}$ & $\begin{array}{l}\text { Automation and } \\
\text { transmission engineering } \\
\text { Long established, } 50 \\
\text { years } \\
\text { Patient development } \\
\text { Bootstrapping } \\
\text { Bricolage }\end{array}$ & $\begin{array}{l}\text { I think our staff that we have is a huge advantage, we've got some } \\
\text { very technical and loyal staff, the service side that we provide } \\
\text { compared to a lot of companies I think we do a lot of servicing for } \\
\text { customers, that some of the big multinationals here just cannot } \\
\text { offer, they have a very tight structured way that they do business } \\
\text { dictated by their overseas parent company---we can be very } \\
\text { proactive for a customer, working on site and ---making machinery } \\
\text { work for customers--- we not only get to see the managing director }\end{array}$ \\
\hline
\end{tabular}




\begin{tabular}{|l|l|}
\hline & $\begin{array}{l}\text { and the production guy, we get to see the chief engineer, we also } \\
\text { get to see the apprentice because they'll drag the apprentice out, he } \\
\text { might be told we need you to go and sort that thing out on that } \\
\text { machine down there, he'll come and say remember that thing on } \\
\text { that trailer I saw a few weeks back, he says that's what I need on } \\
\text { that machine, whereas we might not have got that sort of enquiry, } \\
\text { and that apprentice or the young engineer or whatever who never } \\
\text { gets to see our technology, all of a sudden he's getting to see that } \\
\text { and he can relate it to what he requires in his work, and hopefully } \\
\text { he gets into a position of power one day and decision making, he } \\
\text { might remember us, we can start to build that relationship and we } \\
\text { have, we've had over the years about } 6 \text { years now and some of } \\
\text { those early guys, they still remember when they were on the } \\
\text { workshop floor and they saw us, and they might be a charge hand } \\
\text { now }\end{array}$ \\
\hline
\end{tabular}

Key

\begin{tabular}{|l|l|}
\hline \multicolumn{2}{|c|}{$\mathrm{R}=$ Respondent } \\
\hline FE & Founding entrepreneur \\
\hline NPD & New product development manager \\
\hline MD & Managing director \\
\hline
\end{tabular}

\section{FOOTNOTES}

\footnotetext{
${ }^{i}$ The SCIF Scheme is a Fund operated by New Zealand Venture Investment, an early stage Co-Investment Scheme, which encourages early stage business angel financing through matching co-investment partners (see http://www.nzvif.co.nz/seed-co-investment-overview.html
} 
